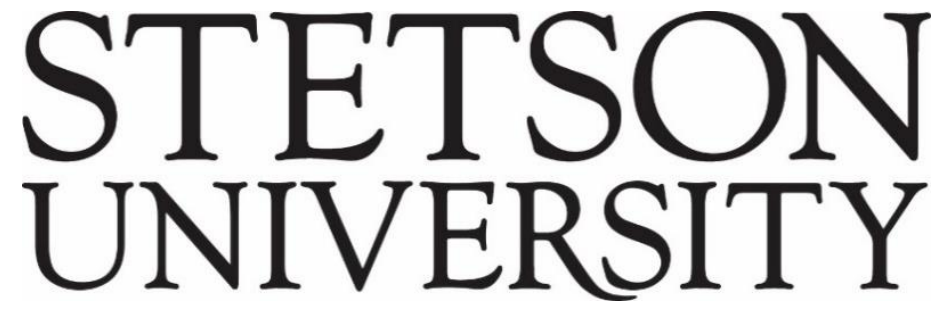

Voices of Reform: Educational Research to Inform and Reform

Volume 3 • Issue $1 \bullet$ Article 4

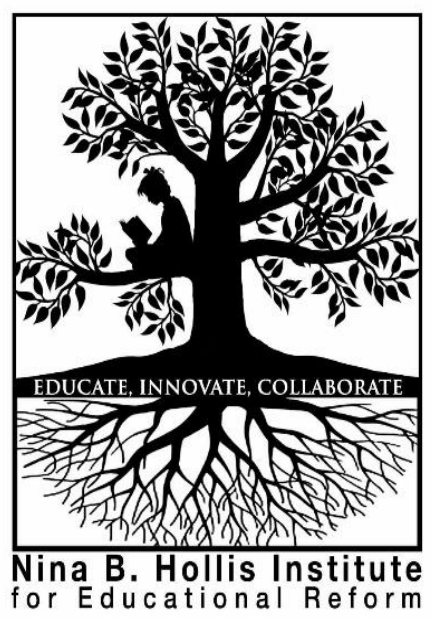

May 2020

\title{
The Rhetorical Machinations of SB 1720: Defunding Developmental Courses
}

Holly Larson

Seminole State College of Florida

Follow this and additional works at: http://www.voicesofreform.com

Recommended Citation

Larson, H. (2020). The rhetorical machinations of SB 1720: Defunding developmental courses. Voices of Reform, 3(1), 77-90. Retrieved from https://www.voicesofreform.com/article/12773-the-rhetorical-machinations-of-sb-1720defunding-developmental-courses doi: 10.32623/3.00006

http://dx.doi.org/10.32623/3.00006

Revisions

Submission date: November $4^{\text {th }}, 2019$

$1^{\text {st }}$ Revision: November $19^{\text {th }}, 2019$

Acceptance: December 6 ${ }^{\text {th }}, 2019$

Publication date: May $1^{\text {st }}, 2020$ 


\title{
The Rhetorical Machinations of SB 1720: Defunding Developmental Courses
}

\author{
Holly Larson ${ }^{1}$ \\ ${ }^{1}$ Department of English \\ Seminole State College of Florida, United States \\ larsonh@seminolestate.edu
}

\begin{abstract}
The purpose of this paper is to not analyze how effective or ineffective Senate Bill 1720 has been since its implementation five years ago; rather, the paper's guiding goal is to closely examine a report recently published in February 2019 by The Center for Postsecondary Success (CPS) at Florida State University, claiming SB 1720 a success. In the report, Increasing Momentum for Student Success: Developmental Education Redesign and Student Progress in Florida, Shouping, $\mathrm{Hu}$, et al. unequivocally state, "In sum, since the implementation of the developmental education reform in Florida in fall of 2014, there has been an increase in student success ..." (p. 2). My goal is to rhetorically analyze how they construct and deliver their argument, as well as how they situate themselves among their audience, to highlight the interactional, dynamic exchange between stakeholders and writer and expose that this exchange is never neutral, but grounded in a certain time and place. Ultimately, my purpose is to show that this report is not simply about declaring and celebrating its perceived success of SB 1720, but rather an exhibit of effective language and argument-making to assure its stakeholders while convincing other audience members that SB 1720 is a successful educational reform.
\end{abstract}

\section{Keywords}

communications, politics, Florida

\section{Introduction}

The Senate Bill 1720 bill implemented in 2014 changed how community colleges as an open-door institution process a diverse student population with various educational backgrounds and numerous levels of foundational skills. The Senate Bill states that any student who entered the $9^{\text {th }}$ grade year in 2003-2004 or later and graduates with a standard high school diploma, as well as any individual actively serving in the military, can 1) opt out of taking a college placement test to assess their skills, 2) opt out of taking any developmental courses, even if they are recommended by advisors, and 3) can go directly into college-bearing courses. Specifically, the bill outlines that 
“developmental education options [are designed] for improving their [students'] communication or computation skills that are essential to performing college-level work, including tutoring, extended time in gateway courses, free online courses" (SB 1720, 2013, p. 23). The "developmental education options" provide a buffet of five alternatives added on to gateway courses that two-year institutions can choose from: 1) modularized lessons to address individual students' educational gaps; 2) co-requisite courses to teach developmental skills alongside college-credit content; 3) compressed courses that address students' academic gaps at an accelerated pace; 4) meta-major courses where students focus on their disciplinary field while patching up academic gaps; and 5) mandated gateway courses as pre-requisites to help students address communication and computation weaknesses before advancing into other college-credit courses (SB 1720, 2013, pp. 27-8).

\section{Marketization of Higher Education: Kairos and Decorum}

To understand the report's rhetorical effectiveness and relevancy in conveying its message that SB 1720 is a success, its kairotic moment must be identified. Rhetorician Roger Thompson (2000) claims how "kairos is central to understanding language's persuasive force," pointing out "what makes language persuasive at a particular time is not only the timing of the event, and not only the situational context of the rhetorical act, but also the intermingling, the unification, and the interdependence of the distinct aspects of timing and propriety" (p. 74). I want to look closely at the latter part of Thompson's definition: "the distinct aspects of timing and propriety." Hu et al. have conducted an annual qualitative and quantitative research on SB 1720 since its implementation in 2014. The 2019 report is the most conclusive study of the bill based on student outcomes in gateway courses from 2011-2016, three years pre and post SB 1720. The timing of this report is therefore obvious: it is in response to Florida legislative changes to developmental courses.

But what may not be so obvious is how the authors are speaking to a larger ongoing narrative that since the 1980's has spun tightly into a coherent, unified message on the marketization of higher education as a consumer-driven commodity that can be quantified and packaged like any salable product. Assistant professor in the Department of Educational Organization and Leadership at University of Illinois Christopher Lubienski (2005) explains how market-oriented reform movements are grounded in the belief that "bureaucratic administration of public services necessarily leads to institutional pathologies such as unresponsiveness to consumers, a lack of innovation, inefficiencies in resource allocation, growing costs, and ineffectiveness in securing desired outcomes" (p. 467). Non-college-credit remediation classes are inherently ineffective because the additional time and money are not directly invested into an associate degree. For example, $\mathrm{Hu}$ et al. (2019) in their introduction state, "Additional time and costs associated with remediation ... discourage students and increase their time to gateway course completion" (p. 3). In the "economic-driven conceptions of the self-interested individual" (Lubienski, 2005, p. 467), time and money are valuable commodities, and students who do not get their money's worth for the time and money invested into their course are unsatisfied customers. Hence, the "additional time and costs" are wasted commodities. 
Further, Hu et al. (2019) emphasize the squander of time when they write, "By the end of the third year, ... remedial math students scoring just below the placement cut-off point earned fewer total college credits compared to their non-remediated peers by a pronounced of 8.3 hours at community college alone" (p. 3). The supplemental 8.3 hours are framed as opportunity cost instead of necessary to help students with computational skills. The fact that students have to invest more money and time into non-college credit courses is problematic for $\mathrm{Hu}$ et al. who also note, "even among those underprepared students who completed developmental requirements, only 15 percent earned an associate's degree within three years, compared to 30 percent for college-ready students" (p. 4). These authors underscore an important tenet of market-driven reform: "Marketing is relatively risk free and inexpensive as compared to attempts to comprehensive curricular reform, and it can easily shore up a school's market by attracting students" (Lubienski, 2005, p. 479). This tenet is a critical reason why Florida legislature voted for and passed SB 1720. State Senator Lori Berman of District 31 underscores this reason, acknowledging "that the legislation was passed in part to save money for both the schools and the students" (L. Berman, personal communication, April 15, 2019). Her comment affirms that SB 1720 is a market-driven reform meant to reduce state's and students' money in developmental courses.

The other aspect of kairos that Thompson points out is propriety. To understand the rhetorical role of propriety in Hu et al.'s report, I want to define propriety with its synonymous pairing, decorum. According to Patricia Ericsson (n.d.), Professor of Rhetorical and Technical Communication, "Decorum is ... not a 'limiting force' but a concept that aids in an 'awareness of, and reaction to, and accommodation of the personalities and interest and words of others,' turning those who employ this concept towards an understanding of the world as one of 'sharing of insight and experience." Decorum identifies how a writer speaks to her audience, such as her choice of language and tone and her use of rhetorical strategies, depending on the type of relationship she wants to and can establish with her audience. Hu et al. (2019) use decorum to accommodate to "the interests" of market-driven reform movement by attributing success to increased student outcome and passing rates. They demonstrate this by stating, "These improvements [increased passing rates in gateway courses] may be attributed to students having few opportunities to drop out and improved alignment with college-level courses. While the effects on longer-term outcome is largely unknown, there is some evidence that accelerated courses may help underprepared students to accumulate credit more quickly . .." (pp. 4-5, emphasis mine). Key words may and more quickly uphold a decorum that supports conventional belief that market reform must be the reason for success, even if all the dots do not connect. It mimics blind faith in capitalism: Adam Smith's invisible hand and its legerdemain that always seems to produce success regardless of circumstances. Hu et al.'s speculative language is an example of this legerdemain where success is pulled out of the sleeve of the invisible hand.

\section{Enthymematic Argument: Reconciling Contradictions in 2018 Reports}

In this section, I want to demonstrate that $\mathrm{Hu}$ et al. use enthymematic argument to reconcile or erase any contradicting data in their 2018 reports that expose a certain amount of mistrust and uncertainty of SB 1720 among administrators and practitioners to provide further credence of their 2019 report that definitively claims SB 1720 a success. Enthymematic argument helps Hu et al. 
reify SB 1720 as a successful market-driven reform. To illustrate how Hu et al. accomplish this, I begin with Sharon Crowley and Debra Hawhee's book Ancient Rhetorics for Contemporary Students (2012) for a clear, succinct definition of enthymeme. They state:

Enthymemes are powerful because they are based in community beliefs. Enthymematic arguments do not have to be spelled out completely, either. The rhetorician may even omit premises or conclusions. The audience will enjoy supplying the missing premises for themselves and may be readily persuaded by the argument because they have participated in its construction. (p. 129)

Crowley and Hawhee make two key points in the definition above: first, enthymemes are grounded in common beliefs; and second, audience members play a critical role in inserting their values and beliefs within the given argument. That is, audience members are deftly led by the writer to a conclusion that is not explicitly stated but nevertheless will be assumed by the reader who will think he naturally and independently arrived on his own at this closing point. It is a sophisticated way of persuading: the rhetor's right hand points the way while the left hand rests on the audience's back steering him forward, all while the audience member thinks he is moving freely on his own. This can be demonstrated in $\mathrm{Hu}$ et al.'s 2018a report Exploring Institutional Change: Administrators' Perceptions of the Fourth Year of Developmental Education Reform in the Florida College System. In this qualitative research, they uncover administrators' uncertain feelings about SB 1720, pointing out that "there were seven institutions that rated themselves lower than 70 in their success in improving student outcomes" (p. 21). In addition, these institutions "expressed frustration that student outcomes did not seem to be improving despite making significant changes to academic and support services" (p. 21).

Interestingly, Hu et al. also note a critical drawback to SB 1720 is the lack of resources, stating, "The greatest challenges faced by colleges in reviewing and responding to data on student outcomes are finding resources to implement solutions" (p. 20). Also, they highlight how "resources to implement new solutions often were not readily available" (p. 20). Equally, they also underscore a weakness in their qualitative data pointing out how "[p]ositions such as those in tutoring or success center and advising staff had the least involvement in reviewing data on student outcomes, which may present a challenge as these positions can bring the micro-level perspective from working directly with students on a daily basis" (p. 20). This information could possibly lead a reader to be, at best, hesitant about SB 1720 and at worst dismissive of the bill. But that is not the conclusion $\mathrm{Hu}$ et al. bring their audience to. Instead, through enthymematic argument, the reader believes the bill may have some bumps, but that these bumps are necessary for a successful reform, for what would real change be if it did not require a little pain and sweat? For example, $\mathrm{Hu}$ et al. counter to the bill's negative side effects by pointing out how institutions are designed to be flexible to meet students' needs and how practitioners have adapted pedagogical behaviors and redesigned curricular content to effectively address these needs. They write, "The most effective changes were hosting professional development opportunities centered on student achievement and increasing faculty time in success centers or tutoring. .." (p. 20). 
Moreover, they celebrate how SB 1720 heightened awareness of students' needs forcing new ways of addressing them, stating, "The most common types of changes in response to reviewing data on student outcomes were changing pedagogy for development courses and implementing early alert systems" (2019, p. 2). Their enthymematic argument could be posited into the following major and minor premises:

Responsible institutions meet students where they are at (major premise)

College-credit gateway courses can accommodate all students (minor premise)

Despite more students entering college-credit courses with limited skills due to SB 1720, responsible institutions can meet students' academic needs (missing premise that audience arrives at)

As Crowley and Hawhee (2012) observe, "rhetors may omit premises that are self-evident to an audience" (p. 129). This is the power in enthymemes: the audience does not see the missing premise as an inherent part of the argument laid out before him. Hence, he believes it is his own logical conclusion.

In "The Body of Persuasion: A Theory of the Enthymeme," professor of rhetorical history Jeffrey Walker (1994) expands Crowley and Hawhee's definition of enthymeme. Referring to the Hellenistic rhetorical tradition, Walker defines enthymeme as "a strategic, kairotic, argumentational turn that exploits a cluster of emotively charged, value-laden oppositions . . to generate in its audience a passional identification with or adherence to a particular stance, and that (ideally) will strike the audience as an 'abrupt' and decisive flash of insight" (p. 53). This is illustrated in Hu et al.'s second 2018b report, entitled Meeting the Needs of Students: Site Visit Report of the Fourth Year of Developmental Education Reform in the Florida College System. They begin their argument celebrating the "fix-it" attitude created from the SB 1720, writing how "[t]his 'fix-it' approach was shared across state colleges, which helped prevent academic silos and allowed for collaborative problem-solving to occur" (p. 7). Yet, interviewing 48 faculty, they give voice to some of the instructors' frustration that contradicts Hu et al.'s "feel good" progress. For example, one faculty decries, "There are students who have been compromised by this" (in Hu et al., p. 8). And another faculty member lamented how instructors in college-level courses must teach "basic developmental skills and waste the time of the students who are academically prepared" (in Hu et al., p. 14). Hu et al. respond to these comments throughout their 38-page report with "a concise, emphatic statement of an emotionally charged opposition" (Walker, 1994, p. 50) to counter and defuse any critique of SB 1720. For example, on page 12, under the bold category, "Meeting the Needs of Students through Instruction: 'Filling in the Gaps," they write, "We learned that many faculty members adapted their courses to better support students, which included supplementing courses with campus resources and technology." And on page 16, they continue with this upbeat "teachers can do anything with pedagogical change" attitude stating that despite the Herculean task of teaching a growing population of underprepared students in gateway courses, "instructors meeting students 'where they are' proved beneficial to improving student writing and 
fostering student success." Interestingly, they ignore the subtext in the following feedback by an English professor speaking about reducing passing rates, when he states, "We changed English 1 in preparation for the onslaught of students who didn't take a PERT. We used to require that you had to pass every core assignment... Well, we softened that. We said that it was your overall average, and if you failed one thing, it wasn't a gatekeeper anymore" (in Hu et al., p. 17). Their immediate response was to couch this narrative with a math professor's personal take who "also reported how his institution supplemented math courses with formal supports, such as peer leaders, and connected students to support centers on campus" (p. 17). Their enthymematic argument was to show the stark opposite of "softened" (read: weak) criteria in post-SB 1720 gateway course by hailing it as yet another example how instructors are miraculously meeting the academic challenges among a growing number of underprepared learners in college gateway courses.

What the missing premise in their enthymematic argument does not reveal is that since the passing of SB 1720 in 2014, funding has been drastically cut from Academic Success Centers (ASC) among all 28 Florida colleges that provide one-on-one tutoring and skills sessions that the math professor mentioned above in Hu et al.'s report referring to "formal supports" he can access for his students. For example, at my institution in the 2016-2017 academic year, 29,067 students used resources offered by ASC. That number increased by 37.4\% in the 2018-2019 academic year to 51,390 students. Yet, state funding allocated for my institution's ASC continues to drop: in 20132014 , prior to the implementation of SB 1720 , funding was at $\$ 703,386$, then fell to $\$ 574,817$ in 2016-2017 and has continued to fall by $6.4 \%$ in the $2018-2017$ academic year and by $6.1 \%$ in the current 2019-2020 year to $\$ 512,000$ (Huston, 2019).

During this time, Florida legislature in 2016 passed the Florida College System PerformanceBased Incentive program, a performance-based funding model for Florida's 28 colleges, competing among each other for funding allocation. The colleges are placed into four categories: gold, silver, bronze and purple. The schools categorized as gold get the largest amount and those designated as purple get the smallest amount. The ranking is judged by four criteria: retention rates, completion rates, job placement, and entry-level pay (2017-2018 performance, 2019). This has created a competitive instead of a collaborative climate putting more pressure on institutions to achieve gold status who must exert more pressure on their faculty to meet the ever-growing academic needs of underprepared students with dwindling formal support to keep retention and completion rates high.

\section{Credibility Appeal: Invented and Situated Ethos}

Crowley and Hawhee (2012) refer to an enthymeme made by Aristotle on the power of ethos, stating, "Since rhetoric is concerned with making a judgment... it is necessary not only to look to the argument, that it may be demonstrative and persuasive but for [for the speaker] to construct a view of himself as a certain kind of person... for it makes a difference in regard to persuasion that the speaker to be a certain kind of person" (pp. 148-149). Aristotle is speaking about the credibility of the rhetor, how the power of her message is grounded in her character, whether she is perceived as trustworthy, knowledgeable, and well-intentioned. 
In this section, I want to focus on the invented and situated ethos of the writers of the 2019 report to show how their credibility is established by various variables: their expertise as accomplished and published university professors at Florida State University's College of Education; their exhaustive 45-page 2019 report with over 34 tables of detailed data; and their relationship to their stakeholder, the Gates Foundation, who partially funded their research. By examining Hu et al.'s invented and situated credibility, I want to show how they "construct a view of [themselves] as a certain kind of person" (Aristotle in Crowley and Hawhee, 2012, 148) that is invested in promoting market-driven reforms.

I first begin with invented ethos. Crowley and Hawhee point out that a rhetor invents his credibility by "using language that suggests that he is an insider, by sharing an anecdote that indicates he has experience of knowledge in a particular area or by describing his qualifications" (p. 154). Invented ethos is particularly important for $\mathrm{Hu}$ et al. since they do not teach gateway courses, nor do they teach at two-year institutions. Simply put, they have not experienced the impact of SB 1720 in their own classrooms. Moreover, their 2019 report does not include any practitioner's point of view or assessment of the bill or the student outcomes. Instead, they use quantitative data from Florida's K-20 Education Data Warehouse, looking at student outcomes in developmental and gateway courses from 2011-2016 examining two groups: cohort-based passing rates and coursebased passing rates. They can overstep this blind spot not being an "organic" insider teaching amongst community college professors who have had to make many adjustments since 2014 by instead referring to hard-driven data to push their narrative of market-oriented reform forward.

In fact, $\mathrm{Hu}$ et al. are not concerned with the micro-level critique of SB 1720. Rather, they continue to focus on the macro level. One could argue that this is not only strategic in how they construct and assert their invented ethos, but also it keeps them objective and impartial to the bill's political fray. However, the latter understanding is part of their construct; that is, it is a manufactured image to appear objective. The data they are mining is as selective as their narrative (note: I will discuss in Section $\mathrm{V}$ how they define and narrow a limited and selective understanding of success). Hence, with conclusive data that shows that more students in general, with a much larger percentage of Black and Hispanic students, have successfully passed Math and English gateway courses, it is hard to refute their argument. They can therefore confidently state, "Overall outcome comparisons on introductory college-level course passing rates and first year credit hour accumulation before and after the 2014 developmental reform show impressive improvement of student progress" (p. 45).

Despite establishing their invented ethos with inside knowledge through data mining, they are not targeting practitioners as their primary audience. Instead, they are appealing to their stakeholders - the Gates Foundation and the Department of Education - who funded their research and who are leading advocates for market-driven educational reforms. They do not need to invent credibility for this audience; instead, they have "built-in" credibility. That is, as accomplished university professors and grant recipients, they are "position[ed] within the social system; because [they have] control over the channels of communication or other aspects of the rhetorical situation; because [they] can influence sources of information and/or the participants' ideology; [and] because [they have] access to powerful people" (Crowley and Hawhee, 2012, p. 163). As a result 
of their situated ethos, they assert their authority and trustworthiness by the quality and rigor of their research. There is no reason to question their claim of impartiality when Hu et al. write, "The opinion expressed are those of the authors and do not represent views of the Institute [FSU] or the U.S. Department of Education, or the Gates Foundation" (p. 1). Yet, an insider knows tacitly that certain behaviors and conventions have more legitimacy over others. There is a reason why microlevel data - actual student writings, comparison of pre- and post-SB 1720 content level, transferrable skills, to name a few - was not analyzed in Hu et al.'s 2019 report and was not part of the definitive declaration that SB 1720 has indeed been an impressive success. Both stakeholders, U.S. Department of Education and Gates Foundations, have publicly stated their distrust of micro-level data as incomplete, inaccurate, and reactionary. For the past two decades they have rigorously funded macro-level research that privileges standardized tests, performancebased data, and other measurable aggregated data. In the special 2013 report in Chronicle of Higher Education, Marc Parry et al. (2013) note how Gates Foundations among a couple other big educational philanthropic players "are pioneering an activist approach to higher-education reform, one that emphasizes systemic change and demands quick, measurable results." Moreover, they point out how "Gates came up with a strategy to break the intergenerational cycle of poverty by doubling the number of low-income students who earn degrees or credentials with labor-market value by the age of 26. . . Success would require an annual increase of some 250,000 graduates." The emphasis is on less time and less money - two critical tenets of market-driven reform. The Gates Foundation has invested $\$ 472$ million since 2006 in U.S. education wanting a return on their money: more students getting through in less time while learning skills that are streamlined to workforce. The nuances and minutiae of micro-level data disrupts and slows this school-to-work pipeline. Hu et al. are well aware of this and what they need to focus on for their own legitimacy and continuing financial support. Their situated ethos, therefore, upholds a certain "ideology [shared by Gates Foundation] - in this case, faith in the superiority of the private business model - [that] drives them. But so does the blinding hubris that comes from power. You don't have to listen or see because you know you are right" (Barkan, 2011). Hence, micro-level data practitioners can provide in addition to their on-the-ground observations and recommendations are ignored. There is no credibility in this type of data.

\section{Stasis Theory: SB 1720 and Success}

Hu et al.'s 2019 report's focus on macro-level data - cohort-based and course-based passing rates in both developmental and gateway courses - underscores a contentious argument: What constitutes success? I turn to stasis theory to help identify and understand the heart of the argument concerning SB 1720 and why the 2019 report is polarizing: one either celebrates the report's finding that SB 1720 is successful or dismisses it as being incomplete, narrow, and highly selective. Crowley and Hawhee (2012) state:

The most satisfactory modern equivalent for stasis seems to be the term issue, which we define as the point about which all parties to an argument can agree that they disagree: this is what is at issue. This point of agreement is important because all parties to an 
argument must know the precise issue on which they disagree;

otherwise, they may just talk past one another. (p. 56)

Stasis theory provides four questions to help rhetors identify the heart of the problem. The four questions consist of the following: 1) Conjecture (existence of an issue); 2) Definition (understanding of the issue); 3) Quality (the value of the issue); 4) Policy (actions to be taken to address the issue) (Crowley and Hawhee, 2012, p. 64). Working through the four stasis questions provide "systematic investigative procedures to help rhetors figure out what arguments are available to them in a given rhetorical situation" (p. 57). The first question (conjecture) articulating the existence of the bill would raise the following concern: Has SB 1720 brought significant changes since its implementation in 2014? Different stakeholders and audience members would agree that, indeed, the bill brought significant changes despite disagreeing if they are positive or negative. Moving along to the second question (definition) poses the following: Referring to the significant changes from SB 1720, what is success? Here is the point of disagreement, where diverse stakeholders and audience members would define success differently and thus respond distinctly to this question based on their definition.

Hu et al. define success as measurable, quantifiable macro-level data based on student outcomes. They state that "there has been an increase of student success as measured by introductory collegelevel course passing rates as measured as the share of students of each cohort who passed the courses and college-level credit hours attempted and earned during the first year of enrollment" (p. 2). Moreover, they underscore this level of success observing that more Black and Hispanic students have passed both developmental and gateway courses showing that "the policy change does seem to be making consistent, substantive and positive impacts on overall student success and equity in student outcomes in Florida College System" (p. 45). Success for Hu et al. and for their stakeholders, the Gates Foundation and Department of Education, is grounded in macro-level, data-driven reform. Lubienski (2005) captures the tenor of their argument defining success "[b]y streamlining these arrangements [reconfiguring gateway courses to accommodate underprepared learners] into a neat consumer - provider relationship, market theory allows schools to focus on the needs of their students - amore business-style conception of 'the public'. .." (p. 467).

In contrast, community college practitioners (faculty and advisors) and administrators would define success differently. They are suspicious of macro-level data, arguing that macro-level data overlooks critical, on-the-ground information that challenges this neat and clean packaged message that SB 1720 is a success. Defining success on a micro level, they would argue that $\mathrm{Hu}$ et al.'s 2019 report is speculative. Using language such as: "Overall, the developmental education redesign in Florida appears to have led to increased success. .." (Hu et al., p. 2, emphasis mine), indicates that there is not yet longitudinal data to show that underprepared students that would have traditionally gone into a developmental class are not only getting the necessary skills but they are also successfully transferring these to other academic courses. Furthermore, they would point out how Hu et al. admit that "the effects on longer-term outcomes is largely unknown" (p. 4).

Moreover, practitioners and administrators at two-year institutions who are in direct contact with underprepared students would look at micro-level data pre- and post-SB 1720 to evaluate the following to define success: 1) rigor of course content; 2) assignments' rubric; 3) exit papers or 
exams; 4) transferrable skills; and 5) metacognitive awareness of rhetorical and computational skills. These criteria are much harder to quantify than passing rates. It not only takes much more time to gather and assess, it also must take into consideration that instructors' teaching style and grading philosophy play a factor in what is "success."

\section{God vs. Devil Terms}

Whether one believes $\mathrm{Hu}$ et al.'s 2019 report that SB 1720 is unequivocally a success or not depends on who the audience is and how they define success. This distinct reading of the report also reveals how the authors use selective and intentional language to convey their message. They use what Richard Weaver (1953) in The Ethics of Rhetoric calls "god terms" and "devil terms." Defining these terms, Weaver states, "By 'god term' we mean that expression about which all other expressions are ranked as subordinate and serving dominations and powers. Its force imparts to the others their lesser degree of force, and fixes the scale by which degrees of comparison are understood" (p. 212). The word "reform" is never mentioned in the 56-page senate bill, yet in the 45-page 2019 report, Hu et al. refer to this word 104 times. "Success" is mentioned 68 times. Both words are "god terms," carrying rhetorical potency. Yet, words such as "funding" and "money" to help aid the reform are never mentioned, and "support" is only used 10 times in the 2019 report underscoring in its absences the lack of resources to implement a real reform. SB 1720 does not allocate any extra funding and the money that was originally spent on developmental courses got channeled back into legislative hands. In contrast, the "devil term" "development" is used 125 times. The reader is constantly aware of its inferior status as a time and money sucking whirlpool spewing out non-college credits. Language is never neutral, it is a system of symbols and an exercise of power. Who is able to speak and who is spoken over determines how language can expand or restrict meaning and representation. Depending on who is speaking and who is spoken over, the 2019 report has either advanced or restricted opportunities to implement changes under SB 1720.

\section{Conclusion: Implications for Practitioners beyond Florida}

The Senate Bill in Florida and its equivalent in other states, such as the Assembly Bill 705 in California and the House Bill 7006 in Tennessee, have raised important and ongoing questions on the role of developmental courses in higher education: Have students who tested into non-bearing college courses felt segregated from their college-level peers? For those who have taken more than one development course, have they felt trapped in a never-ending cycle of remedial work and ended up dropping out, questioning if it is worth investing time, money, and energy -- all limited and precious resources many community college students do not have -- into courses that carry no college credits? Furthermore, have remedial students effectively transferred the foundational knowledge from remedial classes into college-level courses and successfully graduated on time? Although questioning the rationale behind nationwide gutting of developmental programs, Thomas Bailey, Director of the Center at Columbia University's Teachers College, admits, "For better or worse, these discussions [on the role and value of remedial courses] are pushing people to try new approaches" (in Mangan, 2014, p. A3). Indeed, two-year college faculty teaching gateway courses are intensely involved in endless conversations on how best to prepare and support underprepared students. 
These conversations were very much alive at the first national conference for the Two-Year College English Association (TYCA) I attended in spring 2019. A common theme among community college English faculty from several states was how to effectively address underprepared students in college composition due to legislative changes weakening requirements for developmental courses. There was a sense of frustration and fatigue among two-year college faculty on how to accommodate underprepared students who are reading and writing as low as a middle-school level while still teaching a college-level class. Several faculty members expressed dissatisfaction with the traditional developmental programs that "ghettoized" underprepared students from their college-level peers. Accelerated Learning Program (ALP), a co-requisite to target educational gaps and build foundational knowledge while allowing remedial students to take college-bearing gateway courses, was passionately debated on one of the panels. Those supporting co-requisites echoed the founder of ALP Peter Adams's belief that ALP levels the playing field for academically struggling students who deserve to be recognized as college-bound and collegeworthy while providing them an academic support network to be successful, asserting, "We think mainstreaming has a powerful psychological effect for basic writers. When students placed into basic writing are allowed to go immediately into first-year composition, their sense that they are excluded from the real college, that they are stigmatized as weak writers, and that they may not be 'college material' is greatly reduced" (Adam, Gearhart, Miller, and Roberts, 1993, p. 60). And because of this belief that many remedial students feel isolated and demoralized being designated as "poor" and "weak" students, ALP has been implemented in over 300 community colleges nationwide and hailed a success among many of those colleges. There is quantitative and qualitative data that outlines how ALP works and how it has successfully prepared students for the rigorous challenges of college-level courses. For example, Leah Anderst, Jennifer Maloy, and Jed Shahar (2016), collecting and analyzing data on how ALP has both benefited native-English and ESL speakers at Queensborough Community College, underscore Adams' argument contending "how this program works for students with different educational and linguistic backgrounds, in terms of pass rates and retention rates, and specifically how students' perceptions of themselves as writers is impacted by this program" (p. 11).

ALP could be a viable alternative and achievable reform in the state of Florida, as well in other states experiencing the dilution of developmental courses. Indeed, reform is possible. This was a shared belief among my colleagues at the TYCA conference. Still, many felt disillusioned and disappointed by the current situation: their institutions are hamstrung by legislative policies and lack of funding to effectively implement necessary changes. For example, in the state of Florida, SB 1720 highlights co-requisites as one of five optimal choices to address the learning needs of academically unprepared students but denies institutions from using diagnostic test to identify which students need supplemental courses and mandate those students to register for an accelerated learning course; in addition, state funding has drastically been reduced. In the 2017-2018 academic year, funding for remedial courses were cut by $\$ 30.2$ million (Mangan, 2017, p. A24). The rationale for this reduction was attributed to the steep decline in remedial courses being offered. Larry Ahen, Republican chairman of the Florida House of Representatives Higher Education Appropriations Subcommittee, who initially supported a \$58-million cut but ultimately agreed to a lower \$30.2-million reduction, argued that underprepared students are getting the necessary skills outside of remedial classes, hence less funding is needed for developmental 
programs (Mangan, 2017, p. A24). Ahen captures this prevailing belief among legislators and in Hu et al.'s 2019 report that SB 1720 is inherently a reform by forcing institutions to implement effective and creative changes. Moreover, if ALP was to be implemented in Florida's 28 state colleges, there would need to be additional funding to train faculty and administrators to understand the logistics and the curricular design on how these accelerated courses operate. Dawn Coleman (2015), Director at the Center for Applied Research at Central Piedmont Community College, highlights this constant challenge with funding throughout the nation, noting how "sending faculty to training opportunities [to learn about ALP] can be cost prohibitive" (p. 9). Further, she points out, "As ALPs become more well established, the issues of training and scaleup may become a more universal challenge" (p. 9).

Hu et al.'s 2019 report presenting SB 1720 in "god-like" terms, referring to the bill as "reform" 104 times, while calling this reform a "success" 68 times, begs the question: If it is a successful reform then why provide any additional funding? The rationale for continuing to defund remedial courses and supplemental support points to this prevailing attitude: the existing changes are achieving positive results, and administrators, tutoring centers, and teachers are meeting students' academic challenges with their "fix-it" approach. Yet, $\mathrm{Hu}$ acknowledges that implementing reform requires funding stating, "The costs can be incurred for developing different modes of developmental-education courses as required by the law, professional-development costs for faculty and staff members, and increasing the number and workload of the advising and studentsupport professionals, among other things" (in Mangan, 2017, p. A24). Ironically, in an email to Chronicle of Higher Education journalist Katherine Mangan (2017), he admits, "The philanthropists and advocacy groups who pushed for the 2013 legislation rendering developmental education optional did so, in part, with a promise of cost savings. We shouldn't be surprised that legislators will take them up on it" (p. A24).

Using "god-like" or "devil-like" terms to define and explain the changes in developmental programs matter; they shape how one perceives these changes as either reform or as unfulfilled opportunities that require additional time, money, and restructuring to effectively implement to become a reform. Language is more than semiotic symbols; it creates reality and influences decisions. Whether Florida's SB 1720, or of its ilk, California's AB 705 and Tennessee's HB 7006, is a "reform" and a "success" come down to a verbal tug of war; language is used to push and pull its audience through ideas and facts to ultimately understand and support a certain claim. Whether practitioners want to be participants of this tug of war or not, they are by default competing in this race where only the students are the winners or losers as faculty work with and struggle alongside remedial-bound students trying to meet their learning needs. To be competitive at this verbal tug of war, practitioners have to share their experience in their own language, and push and pull the semiotic rope to linguistically position their audience at the very spot where they can see the dayto-day struggles of underprepared students and understand from the ground how to best address these challenges.

\section{References}

Adams, P., Gearhart, S., Miller, R., \& Roberts, A. (2009). The Accelerated Learning Program: Throwing open the gates. Journal of Basic Writing, 28(2), 50-69. 
Anderst, L., Maloy, J., \& Shahar, J. (2016). Assessing the Accelerated Learning Program model for linguistically diverse developmental writing students. Teaching English in the Two-Year College, 44(1), 11-31.

Barkan, J. (2011). Get dough? How billionaires rule our schools. Retrieved from www.dissentmagazine.org/article/got-dough-how-billionaires-rule-our-schools

Coleman, D. (2015). Replicating the Accelerated Learning Program: Updated findings. Retrieved from: http://alpdeved.org/wp-content/uploads/2015/02/ALP-Replication-Study-2015-Final.pdf

Crowley, S., \& Hawhee, D. (2012). Ancient rhetorics for contemporary students ( $5^{\text {th }}$ ed.) Pearson.

Ericsson, P. (n.d.). Rhetorical theory: Kairos and decorum in Beyond the Laments, Beyond the Boundaries: Communicating about composition. Retrieved from public.wsu.edu/ ericsson/Kairos_decorum.doc

Florida College System (2019). 2017-2018 Performance funding model. Retrieved from https://www.floridacollegesystem.com/resources/publications/performance_funding_model_2017-18.aspx

Florida Senate (2013). Senate Bill 1720: Education. Retrieved from www.flsenate.gov/Session?Bill/2013/1720/BillText/er/PDF

Hu, S., Mokher, C., Spencer, H., Hu, X., Park, T., \& Bertrand Jones, T. (2018a). Exploring institutional change: Administrators' perceptions of the fourth year of developmental education reform in the Florida College System. Retrieved from fsu.digital.flvc.org/islandora/ search/exploring\% 20institutional? type=edismax\&collection=fsu\%3Acenter_for_postsecondary_success

Hu, S., Mokher, C., Spencer, H., Hu, X., Park, T., \& Bertrand Jones, T. (2018b). Meeting the needs of students: Site visit report of the fourth year of developmental education reform in the Florida College System. Retrieved from fsu.digital.flvc.org/islandora/ search/meeting\%20the\%20needs?

Hu, S., Park, T., Mokher, C., Spencer, H., Hu, X., \& Bertrand Jones, T. (2019). Increasing momentum for student success: Developmental education redesign and student progress in Florida. Retrieved from fsu.digital.flvc.org/islandora/object/fsu\%3A640590

Huston, J. (2019). ASC/STAR annual program review data. [PowerPoint Slides].

Lubienski, C. (2005). Public schools in marketized environments: Shifting incentives and unintended consequences of competition-based educational reforms. American Journal of Education, 111(4), 464-486.

Mangan, K. (2014, March 21). Remedial educators contest reformers' 'rhetoric of failure.' The Chronicle of Higher Education, pp. A3-A4.

Mangan, K. (2017, May 26). Florida moves to slash funds for remedial education, and college leaders protest. The Chronicle of Higher Education, p. A24.

Parry, M., Field, K., \& Supiano, B. (2013). The gates effect. The Chronicle of Higher Education, 14(6), 26.

Thompson, R. (2000). Kairos revisited: An interview with James Kinneavy. Rhetoric Review, 19(1/2), 73-88.

Walker, J. (1994). The body of persuasion: A theory of the enthymeme. College English, 56(1), 46-65.

Weaver, R. M. (1995). The ethics of rhetoric. Routledge. 